\title{
ANTIPARASITIC BROMOTYROSINE DERIVATIVES FROM THE CARIBBEAN MARINE SPONGE
} Aiolochroia crassa

Elkin Galeano* e Alejandro Martínez

Marine Natural Products Research Group, University of Antioquia, Medellin AA 1226, Colombia

Olivier P. Thomas

Nice Institute of Chemistry, UMR 6001 CNRS, University of Nice - Sophia Antipolis, Parc Valrose, 06108, Nice Cedex 02, France Sara Robledo e Diana Munoz

Program for the Study and Control of Tropical Diseases, University of Antioquia, Medellin, Colombia

Recebido em 8/11/11; aceito em 27/1/12; publicado na web em 15/5/12

\begin{abstract}
Six bromotyrosine-derived compounds were isolated from the Caribbean marine sponge Aiolochroia crassa: 3-bromo-5-hydroxyO-methyltyrosine (1), 3-bromo- $N, N, N$-trimethyltyrosinium (2), 3-bromo- $N, N, N, O$-tetramethyltyrosinium (3), 3,5-dibromo- $N, N, N$ trimethyltyrosinium (4), 3,5-dibromo- $N, N, N, O$-tetramethyltyrosinium (5), and aeroplysinin-1 (6). Structural determination was performed using NMR, MS and comparison with literature data. All isolated compounds were screened for their in vitro activity against Leishmania panamensis, Plasmodium falciparum and Trypanosoma cruzi. Compound 4 showed selective antiparasitic activity against Leishmania and Plasmodium parasites. This is the first report of compounds 1, 4 and 5 in the sponge A. crassa and the first biological activity reports for compounds $2-4$. This work shows that bromotyrosines are potential antiparasitic agents.
\end{abstract}

Keywords: bromotyrosines; Aiolochroia crassa; antiparasitic activity.

\section{INTRODUCTION}

Malaria, leishmaniasis and Chagas diseases number among the most common chronic infections afflicting the world's poorest populations and represent the main causes of disability. These diseases occur mainly in poor areas of tropical and subtropical low-income countries. The most severe type of malaria is caused by the parasite Plasmodium falciparum. In 2010, the World Health Organization (WHO) reported 225 million malaria cases worldwide with a mortality rate close to 781,000 cases/year.1 Leishmaniasis is an infection with diverse clinical forms, which can cause skin ulcerations, mucosa and/ or severe visceral disease. Leishmaniasis is caused by trypanosomatid parasites from the genus Leishmania. According to WHO estimates, 350 million people are at risk of contracting leishmaniasis, approximately 12 million are infected and 2 million new cases are reported each year worldwide. 2 Chagas disease (American trypanosomiasis) is caused by the parasite Trypanosoma cruzi. This zoonosis, in its chronic phase, causes damage to the central nervous system, gastrointestinal system and heart and consequently is often fatal. The WHO has reported nearly 10 million cases of Chagas disease, causing around 10,000 deaths per year, where Latin American countries have the highest incidence of this disease. 3

The high prevalence of these three parasitic diseases the resistance developed by these parasites to current treatments, the reduction of their efficacy and consequent increase in the cost of conventional treatments, highlights the need for novel and effective therapeutic alternatives with fewer or none side-effects. In the search for these new therapeutic options, marine sponges have proven to be a source of bioactive molecules with high pharmacological potential. ${ }^{4}$ In this context, we evaluated the potential of Colombian sponges localized in Uraba Gulf, Southwestern Caribbean Sea, as sources of antiparasitic, cytotoxic, antimicrobial and antitumor agents. ${ }^{4,5}$ In this study, we evaluated the in vitro antiparasitic activity of molecules isolated from the purple-violet spherical morphotype of the marine sponge Aiolochroia crassa (Hyatt 1875,

*e-mail: elgaja@farmacia.udea.edu.co
Verongida, Aplysinidae). This sponge has been reported under different names, such as Suberea crassa (Hyatt, 1875), Aiolochroia ianthella (De Laubenfels, 1949), Ianthella ianthella (De Laubenfels, 1949) and Ianthella ardis (De Laubenfels, 1950). ${ }^{6}$ Aiolochroia crassa, akin to other marine sponges of the order Verongida, is of great interest because this group of sponges is characterized by the production of brominated metabolites which are biogenetically related to tyrosine. For this reason, bromotyrosine metabolites have been considered as potential chemotaxonomic markers of sponges of the order Verongida. ${ }^{7} \mathrm{~A}$ wide range of biological activities have been reported for these compounds including antimicrobial, enzymatic, cytotoxic and antiparasitic activities. ${ }^{8}$ A previous study on the sponge $A$. crass $a$ led to the discovery of antimicrobial activity of its extracts, ${ }^{9}$ and the isolation and identification of several bromotyrosine derivatives, namely: $N$-methylaerophobin-2, aerophobin-1, aerophobin-2, purealidin L, isofistularin-3, araplysillin III, hexadellin $\mathrm{C}, \mathrm{N}, \mathrm{N}, \mathrm{N}$-trimethyl-3-bromo-4-O-methyltyrosine and $N, N, N$-trimethyl-3-bromotyrosine. ${ }^{6,10}$ Aeroplysinin 1 and ianthelline were reported from the sponge Ianthella ardis. ${ }^{11}$ No chemical studies have been reported for the other synonyms of the sponge Aiolochroia crassa. ${ }^{12}$

In this work, 6 known bromotyrosine derivatives were isolated and tested for the first time against L. panamensis, P. falciparum and $T$. cruzi. Therapeutic indices were calculated by dividing the antiparasitic activity of the compounds by their cytotoxicity against promonocytic macrophage cell line U937.

\section{EXPERIMENTAL}

\section{Instruments and reagent}

Optical rotations were measured on a BTI-162 polarimeter, while UV measurements were performed on a Varian Cary 300 Scan UV-visible spectrophotometer. Infrared spectra were acquired on a PerkinElmer Paragon 1000 FT-IR spectrophotometer. NMR data were collected on a Bruker Avance $500 \mathrm{MHz}$ spectrometer using deuterated NMR solvents supplied by Sigma-Aldrich. Spectra were referenced 
to residual ${ }^{1} \mathrm{H}$ and ${ }^{13} \mathrm{C}$ in the deuterated solvents. Low resolution electrospray ionization (ESI) mass spectra were obtained with a Bruker Esquire 3000 Plus spectrometer in the positive or negative mode by the direct injection method. The solvents used (MeOH and $\mathrm{H}_{2} \mathrm{O}$ ) were HPLC grade and obtained from Merck. The formic acid (FA) used was HPLC grade and supplied by Sigma-Aldrich. HPLC purifications were carried out on a Waters 600 system equipped with a Waters 717 plus autosampler, a Waters 996 photodiode array detector and a Sedex 55 evaporative light scattering detector (Sedere, France).

\section{Sponge material}

A specimen of the marine sponge Aiolochroia crassa was collected at a depth of about $10 \mathrm{~m}$ from Urabá Gulf, Caribbean Sea, Colombia ( $\left.8^{\circ} 40^{\prime} 14^{\prime \prime} \mathrm{N}, 77^{\circ} 21^{\prime} 28 \mathrm{~W}\right)$ in October 2008 and identified by S. Ospina. A voucher sample (INV-POR 0075) has been deposited in the sponge collection of Museo de Historia Natural Marina de Colombia, Invemar. The sponge was kept frozen at $-20{ }^{\circ} \mathrm{C}$ from time of collection until the extraction process.

\section{Extraction and isolation}

A portion of A. crassa (419 g wet) was freeze-dried and ground to obtain a dry powder ( $96 \mathrm{~g}$ ), which was extracted three times with a mixture of $\mathrm{MeOH} / \mathrm{CH}_{2} \mathrm{Cl}_{2}(1: 1)$ at room temperature for $15 \mathrm{~min}$ in an ultrasonic bath to give $20.5 \mathrm{~g}$ of crude extract after concentration under reduced pressure. The crude extract was fractionated by RPC18 vacuum liquid chromatography (elution with $500 \mathrm{~mL}$ of each solvent in a decreasing polarity gradient of $\mathrm{H}_{2} \mathrm{O} 100 \%(\mathrm{~F} 1,749.3$ mg), $\mathrm{H}_{2} \mathrm{O}-\mathrm{MeOH}$ 1:1 (F2, 657.2 mg), $\mathrm{H}_{2} \mathrm{O}-\mathrm{MeOH}$ 1:3 (F3, 310.3 $\mathrm{mg}$ ), $\mathrm{MeOH} 100 \%$ (F4, $364.3 \mathrm{mg}$ ), $\mathrm{MeOH}-\mathrm{CH}_{2} \mathrm{Cl}_{2}$ 3:1 (F5, 197.6 $\mathrm{mg}$ ) and $\mathrm{CH}_{2} \mathrm{Cl}_{2} 100 \%$ (F6, $\left.43.1 \mathrm{mg}\right)$ ). Samples were further purified by phenyl-hexyl semi-preparative HPLC column chromatography (Phenomenex Gemini, 10 mm x $250 \mathrm{~mm}, 5 \mu \mathrm{m}, 3.0 \mathrm{~mL} / \mathrm{min}$ ), using gradient elution from $20 \% \mathrm{MeOH}+0.1 \% \mathrm{FA}$ to $50 \%$ over $25 \mathrm{~min}$. The following were isolated from F2: 1 (4.4 mg, 0.14\%), 2 (1.06 $\mathrm{mg}, 0.03 \%), 3$ (1.28 mg, 0.04\%), 4 (0.77 mg, 0.02\%), 5 (1.06 mg, $0.03 \%)$ and $6(1.54 \mathrm{mg}, 0.05 \%)$, Figure 1.

\section{3-Bromo-5-hydroxy-O-methyltyrosine (1)}

Yellow solid; -10.5 ( $c$ 0.04, MeOH); $\mathrm{UV}(\mathrm{MeOH}) \lambda_{\max } \mathrm{nm}(\log \varepsilon)$ 217.0 (3.00) and 283.2 (2.84); IR (neat) $\lambda_{\max } 3200,2935,1630,1580$,<smiles>COc1c(O)cc(C[C@H](N)C(=O)O)cc1Br</smiles><smiles>CN(C)[C@@H](Cc1ccc(O)c(Br)c1)C(=O)O</smiles><smiles>COc1ccc(C[C@H](C(=O)O)N(C)C)cc1Br</smiles><smiles>C[C@H](Cc1cc(Br)c(O)c(Br)c1)[N+](C)(C)C</smiles><smiles>COc1c(Br)cc(C[C@H](C(=O)O)N2CCC2C)cc1Br</smiles><smiles>COC1=C(Br)[C@@H](O)[C@](O)(CC#N)C=C1Br</smiles>

Figure 1. Bromotyrosine-derivatives isolated from the marine sponge Aiolochroia crassa
1150 and $750 \mathrm{~cm}^{-1} ;{ }^{1} \mathrm{H}$ NMR data $\left(500 \mathrm{MHz}, \mathrm{CD}_{3} \mathrm{OD}\right) \delta 7.60 \mathrm{~s}(1 \mathrm{H}$, H-2), $7.38 \mathrm{~s}(1 \mathrm{H}, \mathrm{H}-6), 3.83 \mathrm{~m}$ (1H, H-8), $3.75 \mathrm{~s}$ (3H, OMe), $3.17 \mathrm{~m}$ (1H. H-7a), 3.23 m (1H, H-7b); ESI-MS m/z 290 (100\%) [M+H] $]^{+}$, $292(96 \%)$. Spectroscopic NMR and MS data matched those previously published. ${ }^{13}$

\section{3-Bromo- $N, N, N$-trimethyltyrosinium (2)}

Light brown solid; -8 (c $0.04, \mathrm{MeOH}) ; \mathrm{UV}(\mathrm{MeOH}) \lambda_{\max } \mathrm{nm}$ ( $\log \varepsilon$ ) $278.5 \mathrm{~nm}$ (3.04); IR (neat) 3400, 1635, 1565, 1050 and 655 $\mathrm{cm}^{-1}$. ESI-MS m/z 302 (82\%), 304 (100\%) [M] $]^{+}$. Spectroscopic NMR and MS data matched those previously published. ${ }^{14}$

\section{3-Bromo-N,N,N,O-tetramethyltyrosinium (3)}

Brown solid; -5 (c 0.01, MeOH); UV (MeOH) $\lambda_{\max } \mathrm{nm}(\log \varepsilon)$ 277.3 (3.0); IR (neat) 3350, 1630, 1550, 1055 and $650 \mathrm{~cm}^{-1}$. ESI-MS $\mathrm{m} / \mathrm{z} 316(100 \%), 318(90 \%)[\mathrm{M}]^{+}$. Spectroscopic NMR and MS data matched those previously published. ${ }^{14}$

\section{3,5-Dibromo- $N, N, N$-trimethyltyrosinium (4)}

Yellow solid; -1 (c 0.03, MeOH); UV (MeOH) $\lambda_{\max } \mathrm{nm}(\log \varepsilon)$ 288.0 (3.04); IR (neat) 3350, 2940, 1630, 1565 and $1150 \mathrm{~cm}^{-1}$; ESIMS m/z 380 (39\%), 382 (100\%), $384(38 \%)[\mathrm{M}]^{+}$. Spectroscopic NMR and MS data matched those previously published. ${ }^{14}$

\section{3,5-Dibromo- N,N,N,O-tetramethyltyrosinium (5)}

Brown solid; -6 (c 0.02, MeOH); UV (MeOH) $\lambda_{\text {max }} \mathrm{nm}(\log \varepsilon)$ 282.0 (3.08); IR (neat) 3350, 2945, 1635, 1570 and $680 \mathrm{~cm}^{-1}$; ESI-MS $\mathrm{m} / z 393$ (46\%), 395 (100\%), 397 (44\%) [M] ${ }^{+}$. Spectroscopic NMR and MS data matched those previously published. ${ }^{14}$

\section{Aeroplysinin-1 (6)}

Yellow solid; +149 (c 0.04, MeOH); UV (MeOH) $\lambda_{\max } \mathrm{nm}(\log \varepsilon)$ $277.2 \mathrm{~nm}$ (3.8); IR (neat) 3390, 2265, 1635, 1575 and $700 \mathrm{~cm}^{-1}$; ESIMS m/z $338(50 \%), 340$ (100\%), $341(8 \%) 342[\mathrm{M}+\mathrm{H}]^{+}$. Spectroscopic NMR and MS data matched those previously published. ${ }^{15}$

\section{Biological assay}

In vitro leishmanicidal activity against axenic and intracellular amastigotes

Axenic and intracellular amastigotes of the GFP-transfected $L$. (V.) panamensis strain (MHOM/CO/87/UA140epir GFP) were used for in vitro testing of leishmanicidal activity.

\section{Activity against axenic amastigotes}

The ability of the compounds to kill axenic amastigotes of $L$. (V.) panamensis was determined based on the viability of the parasites evaluated by the MTT (3-(4,5-dimethylthiazol-2-yl)-2,5-diphenyltetrazolium bromide) method previously described elsewhere. ${ }^{16}$ Briefly, parasites were cultivated in Schneider's medium at $\mathrm{pH} 5.4$ supplemented with $20 \%$ heat-inactivated FBS (incubated for 3 days at $32{ }^{\circ} \mathrm{C}$ ). Subsequently, parasites were harvested, washed and resuspended at 2 x $10^{6}$ axenic amastigotes $/ \mathrm{mL}$ in fresh medium. Each well of a 96-well plate was seeded with $100 \mu \mathrm{L}$ of each parasite suspension and $100 \mu \mathrm{L}$ of the test compound at $20 \mu \mathrm{M}$ as the final concentration was evaluated. Plates were incubated at $32{ }^{\circ} \mathrm{C}$. After $72 \mathrm{~h}$ of incubation the effect of drugs was determined by adding $10 \mu \mathrm{L} /$ well of MTT and incubating at $32{ }^{\circ} \mathrm{C}$ for $3 \mathrm{~h}$. The reaction was stopped and the quantity of formazan produced was measured with a Bio-Rad ELISA reader set at $570 \mathrm{~nm}$. Parasites cultivated in the absence of the compound but maintained under the same conditions were used as controls for growth and viability. Parasites cultivated in the presence of amphotericin B were used as positive controls for leishmanicidal activity. 
Activity against intracellular amastigotes

The effect of the compounds against intracellular amastigotes of L. (V.) panamensis was evaluated by flow cytometry. Briefly, U937 cells were dispensed in 24-well plates at a concentration of 300,000 cells/well, which were treated with $1 \mu \mathrm{M}$ of phorbol myristate acetate (PMA) for $48 \mathrm{~h}$ at $37^{\circ} \mathrm{C}$, after which they were infected with promastigotes of $L$. (V.) panamensis in a stationary growth phase (day 5) in modified NNN medium, at a 1:25 cell/parasite ratio. After $3 \mathrm{~h}$ of incubation at $34{ }^{\circ} \mathrm{C}$ in $5 \% \mathrm{CO}_{2}$, non-internalized parasites were washed and incubated again at $34{ }^{\circ} \mathrm{C}$ and $5 \% \mathrm{CO}_{2}$ to allow differentiation to amastigotes form. After $24 \mathrm{~h}$ of incubation, the compound at $10 \mu \mathrm{M}$ was added. Infected and treated cells were maintained at 34 ${ }^{\circ} \mathrm{C}$ and $5 \% \mathrm{CO}_{2}$ for $72 \mathrm{~h}$. The leishmanicidal effect was measured in a flow cytometer at $488 \mathrm{~nm}$ of excitation and $525 \mathrm{~nm}$ of emission. ${ }^{17}$ Infected cells exposed to amphotericin B were used as a positive control for leishmanicidal activity.

\section{Antimalarial activity against Plasmodium falciparum}

Antimalarial activity was evaluated against the $P$. falciparum NF54 strain in asynchronous cultures. The assay was carried out with $P$. falciparum in 24-well suspension cultures using $\mathrm{O}$ positive human serum, 2\% hematocrit in RPMI-1640 medium supplemented with Hepes, hypoxanthine, glutamine, dextrose and the test compound at $5 \mu \mathrm{M} /$ well. Cultures were maintained at $37{ }^{\circ} \mathrm{C}$ for $48 \mathrm{~h}$ under a $1 \%$ $\mathrm{O}_{2}, 4 \% \mathrm{CO}_{2}$, and $95 \% \mathrm{~N}_{2}$ atmosphere. Chloroquine was used as a control for positive activity. Antiplasmodial activity was determined by DNA analysis using a fluorometric method with ethidium bromide dye (EtBr), and fluorescence was read at an emission of $510 \mathrm{~nm}$ and excitation $590 \mathrm{~nm}^{18}$

\section{Trypanocidal activity}

The in vitro trypanocidal activity was evaluated against the T. cruzi Tulahuen strain. U937 cells in wells of a 96-well plate containing RPMI medium were infected with stationary-phase epimastigotes at a 5:1 parasite: cell proportion. After $24 \mathrm{~h}$, the test compound was added at $10 \mu \mathrm{M}$. Beznidazol was used as a positive control. After 72 $\mathrm{h}$ later, the effect was analyzed colorimetrically for $\beta$-galactosidase activity on a spectrophotometer at $570 \mathrm{~nm} .^{19}$

\section{In vitro cytotoxic activity in mammalian cells}

Cytotoxic activity of compounds was assessed based on the viability of the human promonocytic cell line U937 (ATCC CRL1593.2 ${ }^{\mathrm{TM}}$ ) evaluated by the MTT (3-(4,5-dimethylthiazol-2-yl)-2,5-diphenyltetrazolium bromide) method..$^{18}$ Briefly, cells were grown in 96-wells plates at 100,000 cells/mL in RPMI-1640 supplemented with $10 \%$ FBS and the compound at $20 \mu \mathrm{M}$ in duplicate. The cells were incubated at $37{ }^{\circ} \mathrm{C}$ with $5 \% \mathrm{CO}_{2}$ in air for $72 \mathrm{~h}$ in the presence of the compounds, and then the effect of the drug was determined using an MTT assay as described above by adding $10 \mu \mathrm{L} /$ well of MTT solution $(0.5 \mathrm{mg} / \mathrm{mL})$ and incubating at $37{ }^{\circ} \mathrm{C}$ for $3 \mathrm{~h}$. The reaction was stopped by adding a $50 \%$ isopropanol solution with $10 \%$ sodium dodecyl sulfate for $30 \mathrm{~min}$. Cell viability was determined based on the quantity of formazan produced, which was measured with a BioRad ELISA reader set at $570 \mathrm{~nm}$. As a viability test, cultured cells in the absence of extracts were used; amphotericin B was used as a cytotoxicity control.

\section{RESULTS AND DISCUSSION}

Chemical purification of organic extract of A. crassa afforded 6 pure compounds. The structures were determined by NMR and MS data analyses and compared with literature data. Compound 1 is unknown for this species. This compound was first synthesized in
1968 and patented by Recherche et Industrie Therapeutiques (R.I.T.) as an antihypertensive compound..$^{20}$ Thirty nine years later, it was isolated as a natural metabolite from the red algae Rhodomela confervoides. ${ }^{13}$ Compounds 2 and 3 were first reported from the sponge Pseudoceratina crassa (order Verongida) ${ }^{14}$ and later from Aiolochroia crass $a,{ }^{6}$ and Verongula gigantean. ${ }^{7}$ Compounds 4 and 5 have only been reported from the sponge Pseudoceratina crassa. ${ }^{14}$ Compound 5 was evaluated as an antifouling agent against the zebra mussel (Dreissena polymorpha) exhibiting poor activity. ${ }^{21}$ The $8 S$ absolute configuration was assigned on the basis of the negative optical rotation for the compounds 1-5 and their bibliographic data. ${ }^{6,13,14}$

Aeroplysinin-1 (6) was first isolated from Ianthella ardis, and renamed Aiolochroia crassa in $1970 .{ }^{11}$ The $1 S, 6 R$ absolute configurations was assigned on the basis of the positive optical rotation $(+149)$ for compounds 6 and its bibliographic data $(+186) .^{7}$ This compound was evaluated as an agrochemical agent, evidencing no significant activity as an insecticidal, herbicidal and fungicidal agent. ${ }^{22}$ Compound 6 was also evaluated as an: enzymatic inhibitor of receptor tyrosine kinases evidencing no activity at $<100 \mu \mathrm{M},{ }^{23}$ as an antimicrobial and cytotoxic agent as well as an inhibitor agent for the growth of endothelial cells in the micromolar range (antiangiogenic activity with a selective index of 14). ${ }^{24}$ None of the compounds 1-5 reported in this study have previously been evaluated as antiparasitic agents.

Compounds were tested against malaria, leishmania and Chagas parasites. Cytotoxic activities were evaluated in triplicated in promonocytic macrophage cell line U937 (Table 1). Compound 4 showed a high activity against $L$. panamensis and a moderate activity against $P$. falciparum, with $42 \pm 8.5 \%$ and $24.4 \pm 1.6 \%$ of growth inhibition at 20 and $5 \mu \mathrm{M}$, respectively. Compound 6 was active against $P$. falciparum and T. cruzi showing an inhibition in growth of $32 \% \pm 3$ and $26.6 \% \pm 0.6$ at 5 and $10 \mu \mathrm{M}$ respectively. Compound 1 was weakly active against $L$. panamensis and $P$. falciparum with $16.6 \% \pm 0.8$ and $11.7 \% \pm 0.5$ at 20 and $5 \mu \mathrm{M}$, respectively. Compounds 2 and 3 were only weakly active against $P$. falciparum with an inhibition of $11.6 \% \pm 0.1$ and $16.5 \% \pm 3$ at $5 \mu \mathrm{M}$. Compound 5 showed no activity against the three parasites. Only compound 6 at $20 \mu \mathrm{M}$ proved toxic to the U-937 cells with $92.6 \% \pm 7.7$ of inhibition of growth. These biological activity data are similar to those previously reported for aeroplysinin-1 isolated by our group from Verongula rigida. ${ }^{4}$

\section{CONCLUSIONS}

This is the first report on compounds 1, 4 and 5 from the sponge A. crassa and the first biological activity reports for compounds 2-4. None of the isolated compounds had been previously evaluated against Leishmania, Plasmodium and Trypanosoma parasites, and for this reason, this work is the first report of these bromotyrosines as potential antiparasitic agents. The results demonstrate that compound 4 exhibits interesting in vitro activity against Plasmodium and Leishmania parasites, showing 42 and $24 \%$ parasite growth inhibitions in the range 5-20 $\mu \mathrm{M}$, respectively. The compound displayed a high selective index, showing no cytotoxicity against the cell strain tested. Compound 2 had $11.6 \%$ activity against Plasmodium parasites at 5 $\mu \mathrm{M}$ and had no cytotoxic activity against the cell strain tested at 20 $\mu \mathrm{M}$. Compound 6 was the most cytotoxic agent evaluated, explaining its antiplasmodial and trypanocidal activity. These data, taken together with the antiparasitary activity previously observed by our group in bromotyrosines isolates from the sponge Verongula rigida, ${ }^{5}$ show that the species have the secondary metabolite 6 in common, a highly cytotoxic agent, which can be considered a chemical marker of taxonomic significance for the order Verongida.

Structure-activity analysis allowed the identification of 4, 3,5-dibromo- $N, N, N$-trimethyltyrosinium, as a better antiparasitic agent 
Table 1. In vitro antiparasitic and cytotoxic activities of six compounds isolated from A. crassa

\begin{tabular}{|c|c|c|c|c|c|}
\hline \multirow{3}{*}{ Compound } & \multicolumn{5}{|c|}{$\%$ of growth inhibition ${ }^{\mathrm{a}}$} \\
\hline & \multirow{2}{*}{ U-937 cells } & \multicolumn{2}{|c|}{ L. panamensis } & \multirow{2}{*}{ P. falciparum } & \multirow{2}{*}{ T. cruzi } \\
\hline & & Axenic amastigotes & Intracellular amastigotes & & \\
\hline 1 & $2.5 \pm 0.6$ & $16.6 \pm 0.8$ & $2.7 \pm 0.6$ & $11.7 \pm 0.5$ & $4.2 \pm 0.9$ \\
\hline 2 & 0.0 & 0.0 & $2.6 \pm 0.55$ & $11.6 \pm 0.1$ & 0.0 \\
\hline 3 & $1.8 \pm 0.4$ & $2.1 \pm 0.4$ & $\mathrm{NE}$ & $16.5 \pm 3.0$ & 0.0 \\
\hline 4 & 0.0 & $42.0 \pm 8.5$ & $6.2 \pm 1.3$ & $24.4 \pm 1.6$ & $0.6 \pm 0.2$ \\
\hline 5 & $1.3 \pm 0.3$ & 0.0 & $0.2 \pm 0.04$ & $30.8 \pm 0.5$ & 0.0 \\
\hline 6 & $92.6 \pm 7.7$ & $0.1 \pm 0.03$ & 0.0 & $32.0 \pm 3.0$ & $26.6 \pm 0.6$ \\
\hline Amphotericin B & $53.2^{\mathrm{a}}$ & $60.4 \pm 5.7^{\mathrm{b}}$ & $44.9 \pm 7.1$ & NA & NA \\
\hline Chloroquine & NA & NA & NA & $66.8 \pm 1.3^{\mathrm{c}}$ & NA \\
\hline Benznidazole & NA & NA & NA & NA & $44.5 \pm 2.7^{\mathrm{d}}$ \\
\hline
\end{tabular}

${ }^{a}$ Percentage of inhibition corresponds to the inhibition of the U-937 cells or parasites growth determined by colorimetric MTT method (for U-937 cells and axenic amastigotes of $L$. panamensis at $20 \mu \mathrm{M}$ ), fluorometry (for $P$. falciparum total forms at $5 \mu \mathrm{M}$ ) and colorimetric $\beta$-galactosidase method (for T. cruzi intracellular amastigotes at $10 \mu \mathrm{M})$. Data are expressed as the average from at least two independent experiments, each done in triplicate. ${ }^{b} L e t h a l$ concentration $50\left(\mathrm{LC}_{50}\right)$ for U-937 cells (previously determined in our lab) $=33.2 \mu \mathrm{M}$; Effective concentration $50\left(\mathrm{EC}_{50}\right.$ ) for axenic amastigotes of L. panamensis (previously determined in our lab) $=0.05$ and $0.04 \mu \mathrm{M}$, respectively. ${ }^{\mathrm{c}} \mathrm{EC}_{50}$ for total forms of $P$. falciparum (previously determined in our lab) $=42.6 \mu \mathrm{M} ;{ }^{\mathrm{d}} \mathrm{EC}_{50}$ for intracellular amastigotes of T. cruzi (previously determined in our lab) $=9.3 \mu \mathrm{M}$; NE: Not evaluated due to the high toxicity level; NA: Not applicable because these drugs are not used for these parasites.

than its 4-methoxylated analogues, such as compounds 1, 3 and 5. O-methylation seems to reduce antiparasitic activity. Dibrominated compounds exhibited higher bioactivity than their monobrominated analogue (4 and 5 against 2 and 3). Compound 1, 3-bromo-5-hydro$\mathrm{xy}$-4-methoxy-phenylalanine, is a weakly bioactive leishmanicidal and antiplasmodial agent. Based on these results, we can conclude that a free hydroxyl group in the aromatic ring enhances the bioactivity of the molecules and that hydroxylated and dibrominated compounds are better antiparasitic agents and less cytotoxic than their non hydroxylated and mono-brominated analogues.

This result allows us to determine that compounds 2 and 4 are the most interesting compounds tested against Plasmodium and Leishmania parasites, representing a point of reference for development of new related antiparasitic substances and are currently being evaluated to determine a higher selectivity dosage. Further investigations could include the assessment of in vivo efficacy in animal models, not performed in the current study due to the limited amounts of compound available. The biological activity results obtained for this species and with $V$. rigida highlight the importance of halogenated compounds such as bromotyrosines as antiparasitary agents. Currently, we are working on the synthesis of these compounds and other bromotyrosines derivatives in order to evaluate in vitro inhibitory and lethal concentrations before proceeding with in vivo studies.

\section{ACKNOWLEDGMENTS}

Financial support was provided by CODI (Comité para el Desarrollo de la Investigación, Universidad de Antioquia. CIQF-133). E. Galeano received funds from Colciencias, Doctoral Scholarship 2008. The authors thank to Sven E. Zea for the taxonomic classification, M. Gaysinski for recording the NMR spectra and Y. Upegui for technical assistance in antiplasmodial assays.

\section{REFERENCES}

1. WHO - World Health Organization; World Malaria Report 2010, WHO Press: Geneve, 2010.

2. WHO - World Health Organization; Control of the leishmaniasis, report of a meeting of the WHO Expert Committee on the Control of Leishmaniases, WHO Press: Geneve, 2010.

3. WHO - World Health Organization; Innovation for health, research that makes a difference: TDR annual report 2009, WHO Press: Geneve, 2010.

4. Galeano, E.; Rojas, J. J.; Martínez, A.; Nat. Prod. Commun. 2011, 6, 287; Galeano, E.; Thomas, O. P.; Robledo, S.; Munoz, D.; Martinez, A.; Mar. Drugs 2011, 9, 1902; Galeano, E.; Martínez, A.; J. Mycol. Med. 2007, 17, 21.

5. Márquez, D.; Márquez, M. E.; Martínez, A.; Thomas, O. P.; Lat. Am. J. Pharm. 2011, 30, 392.

6. Gao, H.; Kelly, M.; Hamann, M. T.; Tetrahedron 1999, 55, 9717.

7. Ciminiello, P.; Dell'Aversano, C.; Fattorusso, E.; Magno, S.; Pansini, M.; J. Nat. Prod. 1999, 62, 590; Ciminiello, P.; Dell'Aversano, C.; Fattorusso, E.; Magno, S.; Pansini, M.; J. Nat. Prod. 2000, 63, 263.

8. Xu, M.; Andrews, K. T.; Birrell, G. W.; Tran, T. L.; Camp, D.; Davis, R. A.; Quinn, R. J.; Bioorg. Med. Chem. Lett. 2011, 21, 846; Shaker, K. H.; Zinecker, H.; Ghani, M. A.; Imhoff, J. F.; Schneider, B.; Chem. Biodivers. 2010, 7, 2880; Buchanan, M. S.; Carroll, A. R.; Wessling, D.; Jobling, M.; Avery, V. M.; Davis, R. A.; Feng, Y.; Hooper, J. N. A.; Quinn, R. J.; J. Nat. Prod. 2009, 72, 973; Gorshkov, B. A.; Gorshkova, I. A.; Makarieva, T. N.; Stonik, V. A.; Toxicon 1982, 20, 1092.

9. Kelly, S. R.; Garo, E.; Jensen, P. R.; Fenical, W.; Pawlik, J. R.; Aquat. Microb. Ecol. 2005, 40, 191.

10. Assmann, M.; Wray, V.; van Soest, R. W. M.; Proksch, P.; Z. Naturforsch., C: J. Biosci. 1998, 53, 398.

11. Litaudon, M.; Guyot, M.; Tetrahedron Lett. 1986, 27, 4455; Fulmor, W.; van Lear, G. E.; Morton, G. O.; Mills, R. D.; Tetrahedron Lett. 1970, 11, 4551.

12. MarinLit - database of the marine natural products literature; University of Canterbury. Christchurch, 2011.

13. Ma, M.; Zhao, J.; Wang, S.; Li, S.; Yang, Y.; Shi, J.; Fan, X.; He, L.; J. Nat. Prod. 2007, 70, 337.

14. Albrizio, S.; Ciminiello, P.; Fattorusso, E.; Magno, S.; Pansini, M.; Tetrahedron 1994, 50, 783.

15. Makar'eva, T. N.; Stonik, V. A.; Alcolado, P.; Elyakov, Y. B.; Comp. Biochem. Physiol., Part B: Biochem. Mol. Biol. 1981, 68, 481.

16. Taylor, V. M.; Muñoz, D. L.; Cedeño, D. L.; Vélez, I. D.; Jones, M. A.; Robledo, S. M.; Exp. Parasitol. 2010, 126, 471.

17. Varela, M. R. E.; Muñoz, D. L.; Robledo, S. M.; Kolli, B. K.; Dutta, S.; Chang, K. P.; Muskus, C.; Exp. Parasitol. 2009, 122, 134.

18. Agudelo, C.; Corena-McLeod, M.; Robledo, S.; Vitae 2010, 17, 91.

19. Buckner, F.; Verlinde, C.; La Flamme, A.; van Voorhis, W.; Antimicrob. Agents Chemother. 1996, 40, 2592. 
20. Recherche et Industrie Therapeutiques; 1969, p. 46. (CA 831038).

21. Diers, J. A.; Pennaka, H. K.; Peng, J.; Bowling, J. J.; Duke, S. O.; Hamann, M. T.; J. Nat. Prod. 2004, 67, 2117.

22. Peng, J.; Shen, X.; El Sayed, K. A.; Dunbar, D. C.; Perry, T. L.; Wilkins, S. P.; Hamann, M. T.; Bobzin, S.; Huesing, J.; Camp, R.; Prinsen, M.; Krupa, D.; Wideman, M. A.; J. Agric. Food Chem. 2003, 51, 2246; Yamada, A.; Kitamura, H.; Yamaguchi, K.; Fukuzawa, S.; Kamijima, C.; Yazawa, K.; Kuramoto, M.; Wang, G.-Y.-S.; Fujitani, Y.; Uemura, D.; Bull. Chem. Soc. Jpn. 1997, 70, 3061.
23. Hinterding, K.; Knebel, A.; Herrlich, P.; Waldmann, H.; Bioorg. Med. Chem. 1998, 6, 1153.

24. Córdoba, R.; Tormo, N. S.; Medarde, A. F.; Plumet, J.; Bioorg. Med. Chem. 2007, 15, 5300; Rodríguez-Nieto, S.; González-Iriarte, M.; Carmona, R.; Muñoz-Chápuli, R.; Medina, M. A.; Quesada, A. R.; FASEB J. 2001, 16, 261. 